\title{
Tillykke, du er optaget. Værsgo' at tyvstarte!
}

\author{
Jakob Ousager, ph.d.-stipendiat og e-laringsvejleder, Enheden for Uddannelsesudvikling, Det \\ sundhedsvidenskabelige Fakultet, Syddansk Universitet.
}

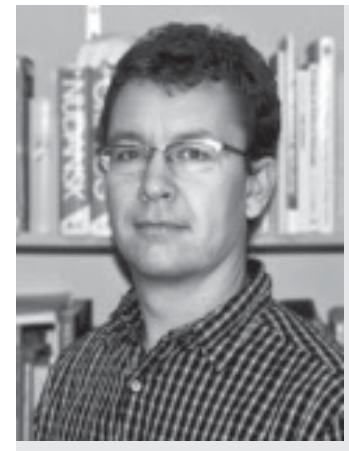

Jakob Ousager er cand.mag i filosofi og dansk og Master i IKT og Læring. Han er ansat ved Enheden for Uddannelsesudvikling, Det sundhedsvidenskabelige Fakultet på Syddansk Universitet, hvor han beskæftiger sig med udviklingsopgaver dels vedrørende tilrettelæggelse af it-støttet undervisning, dels vedrørende undervisning i emner som informationskompetence, videnskabsteori og forskningsmetode. Han er samtidig ph.d.-stipendiat ved Forskningsenheden Helbred, Menneske og Samfund, hvor han forsker i integrationen af humanistiske fag i lægeuddannelsen.

Der stilles store krav til de nye studerende om effektivitet og overblik fra allerforste dag efter studiestart. Og universitetet har en stor interesse $i$ at $y$ de så god starthjolp som muligt. Artiklen beskriver et forstudiestartskursus, som tilbyder de nyoptagne studerende at gå $i$ studietrening allerede for semestret starter. Der rapporteres fra evalueringen, diskuteres evt. problemer, og gives anbefalinger til de, som måtte onske at lave noget lignende til andre studier.

\section{Baggrund: Studiestartsselvhjælp}

Det har altid været universiteternes opgave både at give de studerende mulighed for at lære noget og at kontrollere, at kandidaterne har nået et tilstrækkeligt vidensniveau ved uddannelsens afslutning. Og det har altid været den enkelte studerendes ansvar at gøre sit for at kunne leve op til de afsluttende krav. I dag har vi de fleste steder forladt forestillingen om undervisning som levering af ready-made viden direkte fra professorerne til de studerende. Trenden går mod en fokusering på læring ud fra et konstruktivistisk læringssyn. Ikke at alle universitetsundervisere pludselig er blevet konstruktivister i en dybere epistemologisk eller ontologisk betydning; men en læringsmæssig hverdagskonstruktivisme synes at være bredt accepteret:Vi kan ikke bare hælde viden i hovedet på de studerende. De studerende må selv være aktive, samle sammen, forholde sig til, kort: konstruere viden. Derfor må universiteterne indstille sig på ikke at kunne diktere præcis hvad og hvordan de studerende skal lære. Men samtidig mødes universiteterne af stadig strengere krav om kvalitetssikring, herunder sikring af, at kandidaterne opnår specifik viden, kvalifikationer og kompetencer inden for den normerede studietid.

Hermed bliver det af afgørende strategisk vigtighed for universiteterne at sikre, at de studerende hurtigt bliver gode til selv at styre deres egen videnstilegnelse, at de styrer i den rigtige retning, og at de gør det uden svinkeærinder. Billedligt talt: De studerende skal selv både læse GPS'en, tage bestik af vejrsituationen og føre skibet. Men universitetet skal sørge for, at der er en klar destination, og at infrastrukturen er på plads, så det bliver muligt at navigere $\mathrm{i}$ informationshavet uden overhængende fare for forlis. Derfor er satsningen på at give de nye studerende en god studiestart så vigtig som nogensinde. For nu at blive i sejlerbilledet:Vi må hurtigst muligt have dem i vandet, så de lærer båden, vandet og instrumenterne at kende, og så de i løbet af kort tid har mod på at begive sig ud på åbent vand.

\section{Studiestart i praksis: Bachelor medicin/ klinisk biomekanik som eksempel}

Hvis det nogensinde har været sandt, at det væsentligste talent for en medicin- eller biomekanikstuderende er evnen til at sidde stille og lære udenad, så er det i hvert fald ikke sandt længere.

Der er ikke slækket på kravet om, at de studerende skal opnå viden indenfor nærmere definerede emner. Tværtimod er videnskravet skærpet $i$ den forstand, at det med brug af en nærmere angivet kompetenceterminologi angives, i hvilken grad eller på hvilket niveau den studerende skal have viden om et bestemt emne. Den studerende skal med andre ord ikke blot sørge for at suge den viden til sig, der serveres for hende; hun skal også forholde sig til sin egen videnstilegnelse, så hun prioriterer sin læringsindsats rigtigt. 
Ydermere stilles der krav til den enkelte studerende om, at hun opbygger en digital portfolio, hvis stadigt voksende indhold skal dokumentere, at hun har gennemført en række aktiviteter og erhvervet kompetencer, som ikke testes i moduleksamen. Endelig er det et krav, at den studerende fra første studiedag arbejder med en forskningslignende opgave, som kræver både samarbejdsevner, arbejdsdisciplin og evne til at finde, sortere og videregive informationer på universitært niveau. Kravene til de nye studerende er store - og der er ingen (studie)tid at spilde. Derfor får de nye studerende naturligvis også stillet en række hjælpemidler til rådighed, så de får de bedste forudsætninger for at sætte sig ind i og leve op til de krav, der stilles til dem fra den første dag på studiet. Mulighederne for hjælp er mange; men det er mulighederne for forvirring og overvældelse også. Derfor skal studieintroduktionen hjælpe den nye studerende til hurtigst muligt at blive i stand til at overskue udfordringerne og bruge de værktøjer, der stilles til rådighed. Samtidig skal det helst være sjovt og imødekommende!

\section{Studiet begynder for semesterstart}

Som et led i det samlede introduktionsforløb har vi udviklet et førstudiestartskursus, som de nyoptagne studerende tilbydes at deltage $\mathrm{i}$ i ugerne op til studiestarten. Førstudiestartskurset skal hjælpe de nye studerende til at blive klar til seriøst studie-arbejde fra semestrets første dag. Det indebærer bl.a., at de nye studerende kender de krav, der stilles til dem i det nye studie; ved, hvad der skal ske i den første studietid, og hvad der forventes af dem; og at de kan bruge e-læringsredskabet og andre af de ressourcer, universitetet stiller til rådighed (biblioteket, netværk, studenterportal osv.). Det er håbet, at der efter semesterstart vil være en eller flere i hver studiestartsgruppe, som har deltaget i det frivillige førstudiestartskursus, og som dermed på visse punkter kan fungere som starthjælper for de nye studerende, som ikke har deltaget. Det er også højt prioriteret, at kurset skal støtte de nye studerende i at opbygge studiestøttende, sociale fællesskaber, og at det skal styrke de nye studerendes følelse af, at de er velkomne.

\section{Forstudiestartskursets indhold - rammer for aktiviteter}

Der gælder de samme grundlæggende vilkår for førstudiestartskurset, som for den uddannelse, der introduceres til: Introduktionen kan ikke være en færdig videns- og kundskabsstruktur, der på magisk vis overfores til de studerende. Men vi kan sætte nogle rammer, som de nye studerende tilbydes og inviteres til at udfolde sig indenfor.Vores førstudiestartskursus består netop af sådanne rammer, som giver de nye studerende mulighed for at kickstarte deres universitetsstudie allerede inden semesterstart - med den formodede nysgerrighed overfor studiet som brændstof. De rammer, førstudiestartskurset sætter, omfatter
1) tidspunkt, hvor de nye studerende kan gå i gang med aktiviteterne,

2) stedet, hvor aktiviteterne foregår

3) velkomstmateriale med hilsener fra dem, der er inde, til dem, der er på vej,

4) let adgang til relevante informationer,

5) invitation til aktiviteter og

6) 'værter', der kan give starthjælp til de nye studerendes interaktion med hinanden

\section{Tidspunkt: Fra 3 uger for studiestart}

De nye studerende får besked om optagelsen den 28 . juli. Med førstudiestartskurset giver vi mulighed for at udnytte tiden fra de meddeles optagelse, til studiet rent faktisk starter til at forberede sig bedst muligt på studiestarten. Et motiv er, at de nye studerende helst skal være godt rustet til at gå i gang med seriøst studiearbejde allerede fra første studiedag. Et andet motiv er, at de studerende netop i perioden fra meddelelse om optagelse må formodes at være så motiverede for at lære om det nye studie, som de næsten kan være.

Invitationen til at deltage $\mathrm{i}$ førstudiestartskurset udsendes sammen med studiekortene, dvs. typisk ca. 3 uger før semesterstart. Herefter kan de studerende straks gå $\mathrm{i}$ gang. Der er ikke særlige krav om, hvornår de forskellige aktiviteter skal foregå. Der er heller ingen afslutningsdato; førstudiestartskurset glider sømløst over i de 'rigtige' studieaktiviteter ved semesterstart.

\section{Stedet}

Førstudiestartskurset foregår i den e-læringsomgivelse, der i øvrigt bruges på studiet. Der bruges et virtuelt 'rum', som er tilgængeligt for alle på bacheloruddannelsen. De nye studerende introduceres altså via et rum, hvor der allerede færdes ældre studerende.

Netbaseringen giver stor fleksibilitet, hvilket er særligt afgørende her, fordi de potentielle brugere netop i ugerne op til studiestart kan have mange aktiviteter og planer, som ville umuliggøre deres deltagelse til et bestemt tidspunkt og sted. De nye studerende kan deltage $\mathrm{i}$ førstudiestartskurset på et hvilket som helst tidspunkt og fra en hvilken som helst lokalitet, de måtte ønske - fra det nye kollegieværelse, fra forældrenes sommerhus eller fra en netcafe på den anden side af jorden.

Netbaseringen gør samtidig, at deltagelsen i de studieforberedende aktiviteter i sig selv er en praktisk indførelse i brugen af det e-læringsværktøj, som kommer til at spille en central rolle $\mathrm{i}$ de studerendes samlede studieforløb. I stedet for at de studerende introduceres til e-læringsværktøjet via fx en præsentation efterfulgt af 'laboratorieøvelser' i løbet af de første studieuger, så lærer de værktøjet at kende ved at bruge det i ugerne før studiestarten. 

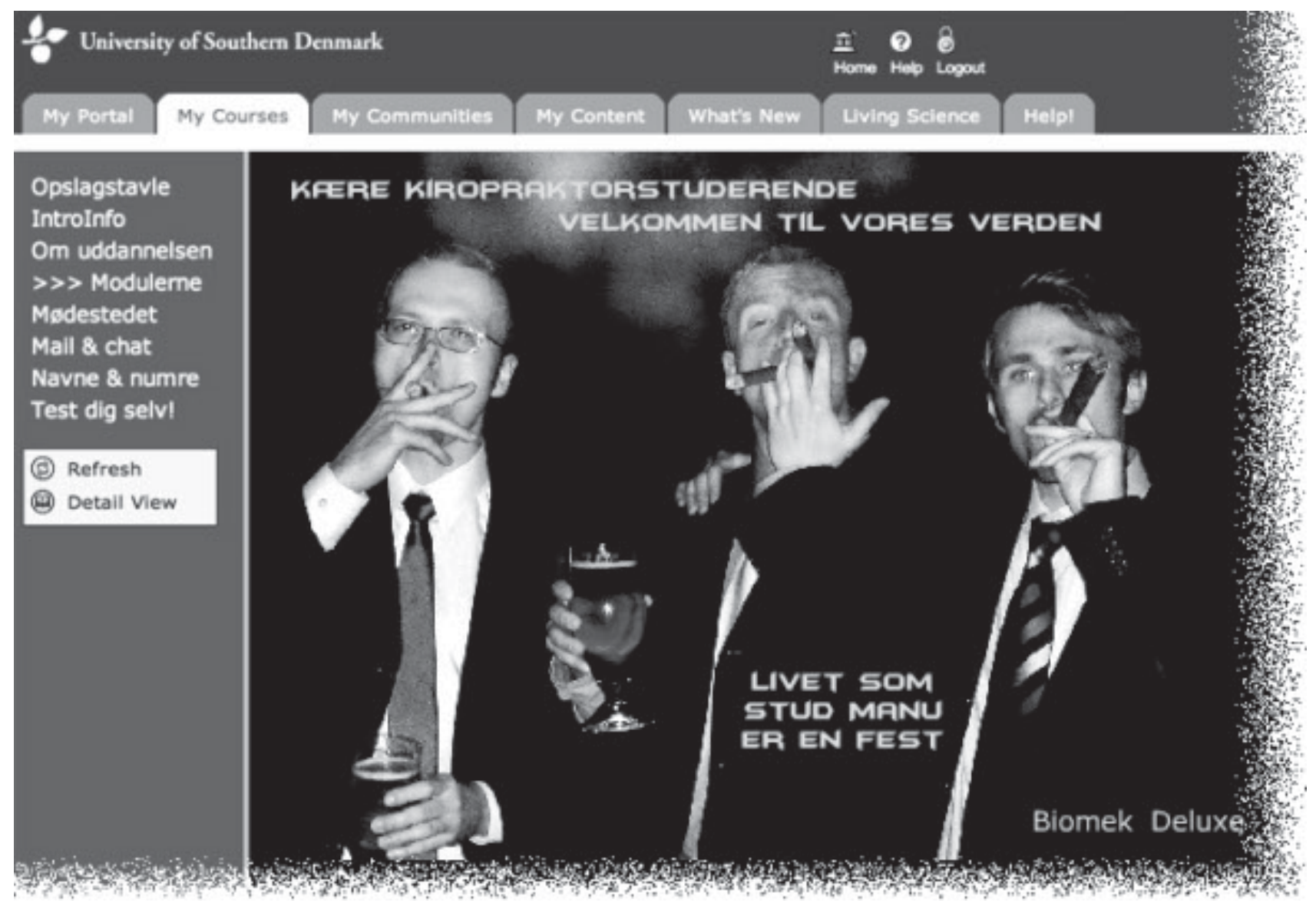

\section{Velkomstmateriale}

Førstudiestartskurset giver adgang til velkomstmateriale med en bred vifte af afsendere:Velkomsthilsener fra studielederne suppleres af hilsener fra bl.a. faglige vejledere og fra studenterorganisationer - fra det lokale festudvalg over studenterrådet til lokalafdelingen af en international forening for medicinstuderende. Og som noget særligt er der en håndfuld 'velkomst-fotobreve', hvor individuelle ældre studerende i ord, billeder og lyd siger velkommen til de nye studerende og viser dem lidt rundt på studiet. Et af velkomstbrevene er en hel lille film, hvor en ældre studerende giver en meget personlig guidet rundtur på campus, i parkerne rundt om, og i byens shopping- og cafemiljø. Endelig indeholder førstudiestarts-netstedet materiale fra de sociale tutorer, der arrangerer studiestartsaktiviteter som fx RUS-ture, pubcrawls osv. Det samlede velkomstmateriale viser de nye studerende, at de er på vej ind $i$ et aktivt og indbydende studiemiljø.

\section{Need to know}

Udover at give adgang til centrale dokumenter som $\mathrm{fx}$ den gældende studieordning, så indeholder førstudiestarts-netstedet en række introducerende tekster om nogle af de muligheder og services, som universitetet stiller til rådighed, og som er af umiddelbar relevans for en ny studerende. Det er fx oplysninger om brugen af den e-mail-konto, som RUS'eren har fået sammen med studiekortet, brugen af trådløst netværk på Campus og på andre studiesteder, oplysninger om biblioteket, om muligheden for at få en SDU-weblog, vejledning $i$ at bygge den digitale portfolio etc.

Teksterne er korte og overskuelige,og er skrevet direkte henvendt til deltagerne i førstudiestartskurset - dvs. til brugere, som ikke i forvejen kan forventes at have nogen som helst viden om universitetets infrastruktur. I mange tilfælde henvises der dog via links til steder i universitetets samlede netsted for mere information om et emne.

Informationer om de konkrete aktiviteter i de første studiedage findes ikke i selve førstudiestarts-netstedet. De findes derimod i et parallelt netsted, som er opbygget på en helt lignende måde, og hvis indgang de nye studerende finder side-om-side med indgangen til førstudiestartskurset.

\section{Invitation til interaktion - quizzer og virtuelt mødested}

Det kan være lige meget med informationer og velkomstbreve, hvis ikke de nye studerende læser materialet. Og hvis de alene læser det, så kan det næsten også være lige meget; hvis målet alene var at give de nye studerende mulighed for at læse om deres nye studie, så var det lige så godt med en pæn lille tryksag.

Quizzer er een måde at invitere til interaktivitet: Studiestartsforløbet indeholder to quizzer, hvor de studerende kan svare på spørgsmål om universitetet og om den uddannelse, de netop er optaget på. Alle spørgsmål kan besvares af den, der har sat sig nogenlunde ind $\mathrm{i}$ de informationer, der i øvrigt gives i førstudiestartskurset. Der er en præmie til den studerende, som op- 


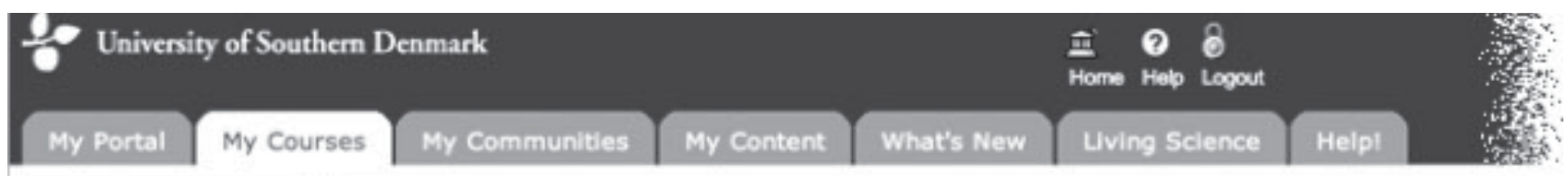

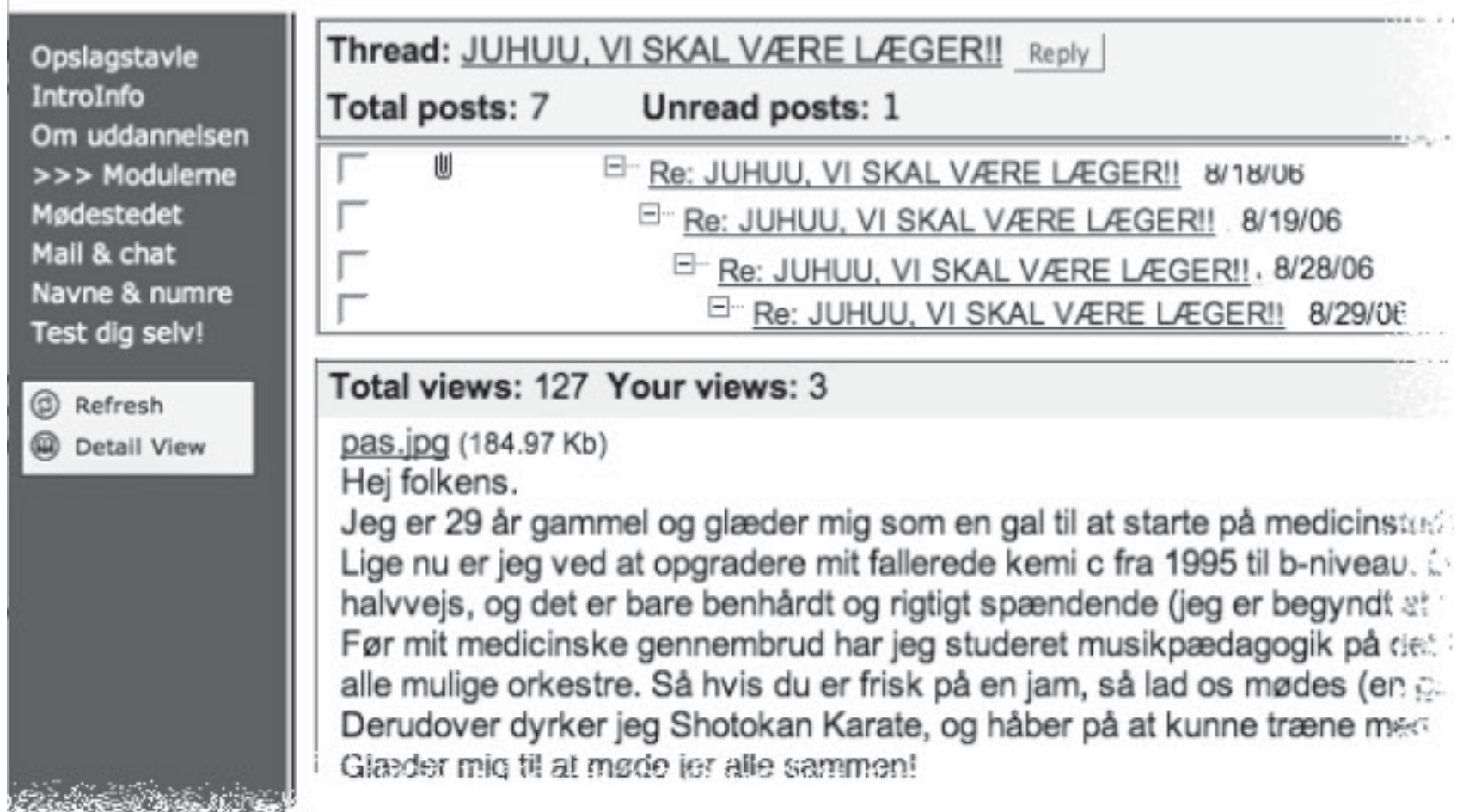

når flest point $\mathrm{i}$ testen. Præmien - en SDU-taske el. lign. - overdrages til vinderen ved den første, officielle velkomstforelæsning.

Det virtuelle mødested er en anden måde at invitere til interaktion på. Mødestedet er et diskussionsforum, hvori de nyoptagne studerende opfordres til at præsentere sig selv og hilse på hinanden.

\section{Verter}

De faglige tutorer er 'virtuelle værter' i mødestedet. De faglige tutorer er ældre studerende, som er ansat til at hjælpe studiestartsgrupperne igennem det første semester. Tutorernes rolle i førstudiestartskurset er i første omgang blot at skrive et indlæg, hvor de præsenterer sig selv og sender en hilsen til de nye. Herefter skal de klikke ind i mødestedet fra tid til anden og svare på indlæg, hvor de måtte finde det passende - en faglig tutor kan fx svare på indlæg, som indeholder præsentationer af en ny studerende, der skal være i den faglige tutors studiestartsgruppe. Overfor de faglige tutorer er opgaven beskrevet som, at de skal betragte sig selv som de opmærksomme værter $i$ et virtuelt cocktail-party.

\section{Erfaringer fra førstudiestartskurset}

\section{Evalueringsmål og -midler}

I evalueringen af førstudiestartskurset har vi i første omgang forsøgt at få et indtryk af, hvordan de stu- derende generelt har modtaget og brugt initiativet. Herudover har vi søgt svar på, om førstudiestartskursets særlige form ser ud til at forfordele visse brugergrupper, som derved risikerer at have et ringere udgangspunkt ved studiestarten.

Anvendelsen generelt - hvor mange har benyttet sig af tilbuddet

Invitationen til at deltage i førstudiestartskurset blev sendt ud til samtlige studerende, som var blevet optaget på bachelorstudiet i medicin/biomekanik pr. 1. september 2006. 174 af de 182 nye studerende loggede på mindst een gang inden semesterstart, hvilket betyder, at $93 \%$ af de nye studerende i et eller andet omgang tog imod tilbuddet om deltagelse i førstudiestartskurset. ${ }^{1}$

Førstudiestartskurset havde i ugerne op til studiestarten dagligt besøg af 10-40 \% af alle brugere, med størst aktivitet i den sidste uge før semesterstart. Nogle studerende besøgte kurset en enkelt gang inden studiestart, mens andre har været der dagligt eller næsten dagligt i hele perioden. Gennemsnitligt havde hver enkelt studerende besøgt førstudiestartsnetstedet 1-2 gange om ugen i hver af ugerne fra netstedet åbnedes til semestret startede.

$56(30 \%)$ af de nye studerende var aktive i det virtuelle mødested. 53 (28\%) af de nye studerende besvarede en eller begge de to quizzer, der blev tilbudt. Ca. en fjerdedel af de studerende var aktive begge steder.

En tilsvarende opgørelse lavet over deltagelsen i førstudiestartskurset for studerende med studiestart i det 


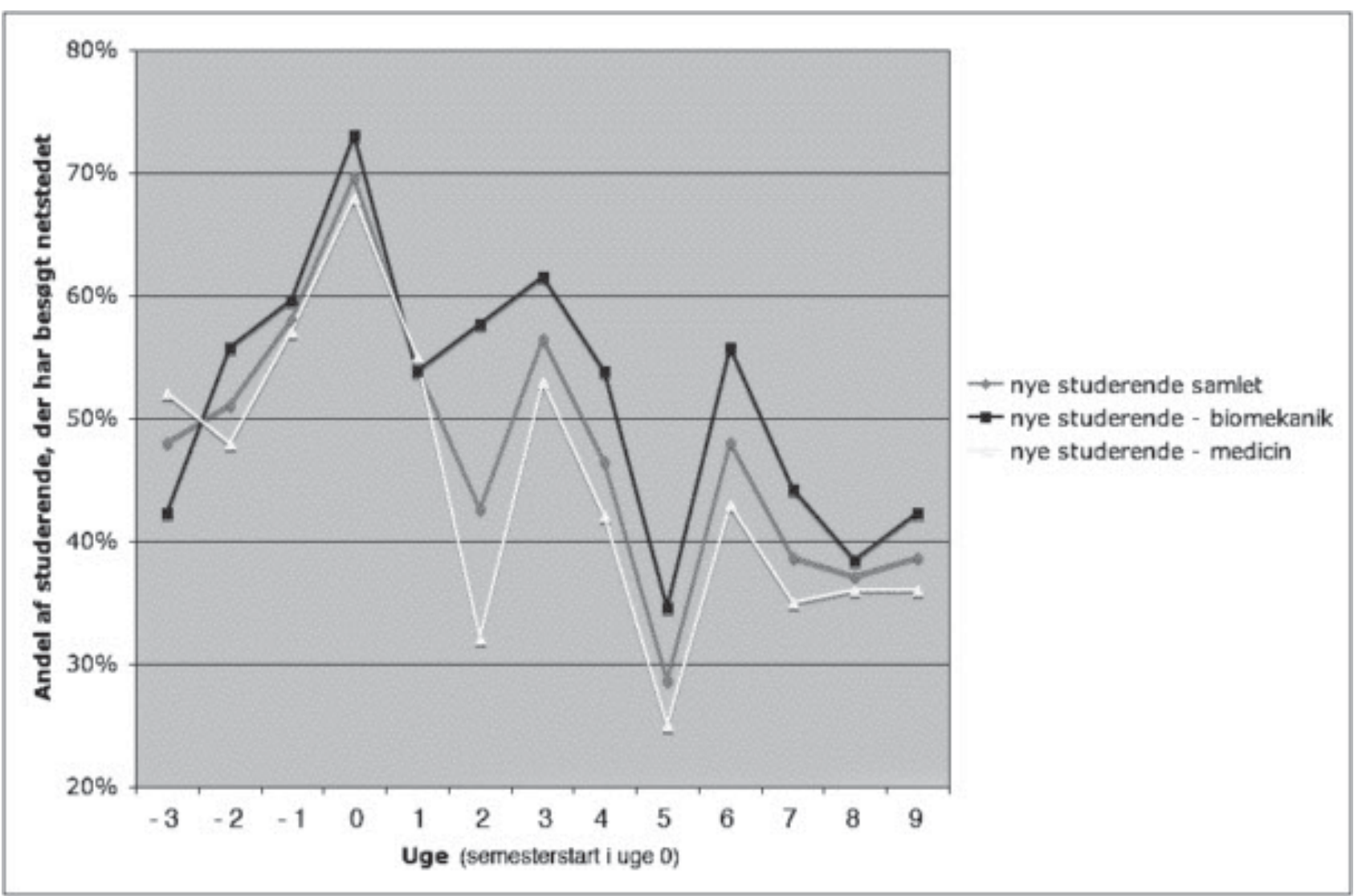

Figur 1. Grafen viser hvor stor en del af de nye studerende, der har besøgt det netsted, som dannede rammen om forstudiestartskurseti ugerne op til og efter semesterstart. Besøgene efter semesterstart kan bl.a. have varet for at se billeder fra rusturen, konsultere guides og hjoelpemateriale, fortsctte brugen af det virtuelle modested, eller se opslag om faglige og sociale arrangementer.

følgende semester viste marginalt højere tal for både deltagelse, brug af quizzer og deltagelse i mødested.

Hvem var mest og mindst aktive?

Data vedrørende de studerendes brug af førstudiestartskursets netsted er blevet nærmere analyseret for at fa et indtryk af, om der kan identificeres grupper af brugere, som ser ud til ikke at blive fanget af den måde, kurset er tilrettelagt på. Man kunne fx forestille sig, at ældre studerende ville være mindre tilbøjelige til at bruge det netbaserede tilbud, eller at andre brugergrupper ikke ville bruge tilbuddet, og dermed i princippet blive 'diskrimineret' $i$ den betydning, at de (i hvert fald teoretisk set) ville være ringere stillet ved studiestarten.

En statistisk analyse ${ }^{2}$ af data om brugen af studiestartsnetstedet viser imidlertid ingen signifikant forskel på brugen, når der ses på parametrene køn og alder. Der kan heller ikke spores nogen forskel i brugen mellem studerende, der er optaget på hhv. kvote 1 og $2 .{ }^{3}$ Der ses $\operatorname{dog}$ en lille, men signifikant forskel mellem de to studieretningers brug af netstedet: De studerende, der er optaget på biomekanikstudiet, var samlet set en lille smule mere aktive, end de studerende, der var optaget på medicinstudiet.

\section{Evalueringsresultater - hvad siger de studerende}

Førstudiestartskurset er evalueret som led i den almindelige evaluering af det første af bacheloruddannelsens 12 moduler. De studerende har ivrigt benyttet evalueringens mulighed for at komme med generel ros og kritik, men der er ikke mange kommentarer, der direkte retter sig mod førstudiestartskurset. Det fremgår meget tydeligt af evalueringskommentarerne, at de studerende har taget rollen som aktive studerende på sig, og at de aktivt bruger e-læringsmediet. Det er glædeligt - men vi har ikke belæg for at hævde, at aktiviteten havde været mindre uden førstudiestartskurset.

På et opfølgningsmøde til evalueringen mødte en mindre, men aktiv gruppe studerende op for at kommentere bl.a. førstudiestartskurset. Både faglige tutorer og nye studerende var positive overfor initiativet. Eneste ændringsforslag var, at mødestedet fremover skulle indrettes med et rum til hver studiestartsgruppe, fordi det kunne føles utrygt at skrive sin præsentation $i$ et forum med henved 200 mulige deltagere.

\section{Diskussion - virker studiestartsprojektet efter hensigten?}

Vi ved, at langt størstedelen af de nye studerende i et eller andet omfang har taget imod tilbuddet om deltagelse i førstudiestartskurset, og at godt halvdelen 
af de studerende har deltaget aktivt ved at skrive i det virtuelle mødested og/eller tage en quiz.Vi ved også, at de nye studerende har været $i$ stand til straks efter studiestarten at gå i gang med de krævede aktiviteter, uden at der tilsyneladende har været tvivl om, hvad der skulle foregå, og hvilke værktøjer, der var til rådighed osv.

Men vi ved ikke hvilken rolle førstudiestartskurset reelt har spillet.Vi ved ikke, om aktiv deltagelse i førstudiestartskurset giver sig udslag i ringere, uændret eller bedre studiesucces for de, der har været aktive. Den viden kunne man ellers hævde var et nødvendigt grundlag for at vurdere, om det overhovedet er umagen værd med sådan et førstudiestartsursus. Det ville også være nærliggende at undersøge, fordi de nye studerende i praksis deler sig i to lige store grupper: Dem, der tager aktivt del i førstudiestartskurset, og dem der ikke gør. ${ }^{4}$ Så hvorfor ikke blot sammenligne studieprogressionen for de to grupper?

Principielt ville en sådan sammenligning kunne have to forskellige udfald: Den kunne enten vise, at der er eller ikke er forskel på de to gruppers studiesucces. Det ville imidlertid ikke vise, om førstudiestartskurset som sådan bidrager eller ikke bidrager positivt til at forberede de studerende på deres studie. Hvis der ikke er forskel, så kan det betyde, at før-studiestartsaktiviteterne faktisk ikke gør nogen forskel. Men det kan lige så godt betyde, at de, som har deltaget i aktiviteterne, har været $\mathrm{i}$ stand til at hjælpe deres medstuderende - dvs. at aktiviteterne har virket præcis efter planen. Hvis der på den anden side faktisk viste sig en forskel, så kunne det betyde, at de studerende, som har taget del i aktiviteterne, har haft et (positivt eller negativt) udbytte af det. Men forskellen kunne lige så godt skyldes særlige karakteristika ved de studerende, som hhv. deltager/ ikke deltager i den slags aktiviteter.

Man ville kunne lave et undersøgelsesdesign, hvor man via randomisering forsøgte at måle isoleret på effekten af førstudiestartskurset. ${ }^{5}$ Vores vurdering er imidlertid, at der uanset en evt. dokumenterbar effekt på de studerendes studieprogression er gode grunde til at lave et førstudiestartskursus som det omtalte.

En væsentlig grund er, at brugen af førstudiestartsnetstedet i sig selv bliver en øvelse i at bruge et værktøj og et kommunikationsmedium, som under alle omstændigheder bliver en central del af de nye studerendes studiehverdag. Når de studerende i forstudiestartskurset interagerer med hinanden via nettet, så gør de det via netop det kommunikationsværktøj, der straks efter studiestarten skal bruges $i$ arbejdet med den første større opgave. Og når de studerende deltager $\mathrm{i}$ de 'intro-quiz'er', der stilles til rådighed, så foregår det i samme værktøj, som senere bruges i den 'rigtige' undervisning. Det er svært at se andet, end at den øvelse i bedste fald kan gavne de nye studerende, og i værste fald ikke kan skade.

En anden grund er, at en uddannelse vel altid vil informere sine kommende studerende bedst muligt om uddannelsen. Det ønske honoreres via førstudiestartskurset. Kurset sigter så bare samtidig på mere aktivt at initiere de nye studerendes egen opbygning af en forståelse af medicin/biomekanikstudiet og deres egen rolle i det. Lidt højtravende kunne man sige, at førstudiestartskurset skal støtte de nye studerendes begyndende konstruktion af sig selv som studerende ved en bestemt uddannelse. Hvis vi antager, at den studerendes konstruktion af sig selv som studerende er en aktiv, diskursiv proces, så må vi videre antage, at konstruktionsarbejdet kan støttes ved at støtte den diskursive aktivitet. Med andre ord: Når de nye studerende deltager i mødestedet, så er de allerede i gang med at øve sig $i$ at være universitetsstuderende, med hvad det indebærer af opbygning af selvforståelse og af sociale netværk.

Endelig sender førstudiestartskurset med dets opfordring til de nye studerende om aktiv medvirken et signal om de forventninger, der i det hele taget stilles til deltagerne $i$ et tidssvarende universitetsstudium. Kurset sender den besked til de nye studerende, at "Vi er glade for at se jer, vi stiller informationer og ressourcer til rådighed for jer - men vi forventer andet og mere, end at I blot tager imod og terper for jer selv."

\section{Hvad skal der til - og kan andre gøre det samme?}

De studerende fra den ene af vores to uddannelser var generelt mere aktive i kurset end de studerende på den anden uddannelse. Hvis der kan påvises en 'studie-relateret' forskel i motivationen, selv når det er så nært beslægtede uddannelser, der sammenlignes, så er det nærliggende at forestille sig, at forskellen ville være endnu mere udtalt, hvis der sammenlignedes mellem studerende på mere væsensforskellige uddannelser. Det er med andre ord både af denne og andre grunde ikke til at vide, om et lignende førstudiestartskursus ville få en lignende modtagelse på et andet studie.

Hvis man på en anden uddannelse vil prøve med noget lignende, så vil vi pege på nogle forhold, som vi mener bør være på plads, hvis der skal sikres det bedst mulige udgangspunkt for kurset.

For det forste skal man i det hele taget ikke undervurdere den opgave, der ligger $i$ at designe, tilrettelægge og realisere førstudiestartkurset, så det reelt har noget at tilbyde de nye studerende, samtidig med at det er tilstrækkeligt 'tjekket' og indbydende.

For det andet er det væsentligt, at der afsættes ressourcer til at sikre en eller anden form for isbrydning $\mathrm{i}$ førstudiestartskurset. I vores tilfælde var det de lønnede faglige tutorer (ældre studerende), der fik det som en del af deres arbejdsopgave at bryde isen i det virtuelle mødested. Fra andre lignende førstudiestartsforsøg har vi erfaring for, at de nye studerende forståeligt nok kan føle det lidt svært at skulle skrive de første indlæg i et helt nyt og tomt diskussionsforum - her hjælper det, hvis en ældre studerende har vist vejen. 
For det tredje kan et kursus af denne art ikke laves af en enkelt underviser alene, eller for den sags skyld af en gruppe undervisere. Der kræves et udstrakt samarbejde både med en række indholdsleverandører og med administrative organer. Indholdsleverandørerne omfatter i vores eksempel studieledere, personer med viden om de forskellige relevante ressourcer (netværk, email, bibliotek, studieordning osv.), faglige vejledere/ studievejledere, repræsentanter fra forskellige studenterorganisationer og 'almindelige' ældre studerende med lyst til at lave velkomstbreve. Som minimum skal der også laves aftaler med de administrative organer, der sørger for udsendelse af informationsmateriale til de nyoptagne studerende. I de fleste tilfælde vil der også skulle laves særlige administrative arrangementer for at sikre, at de studerende kan få adgang til det relevante 'rum' i e-læringsværktøjet allerede for den officielle studiestart. Her kan der være brug for noget benarbejde, og for at kunne gå lidt udenfor de normale procedurer.

\section{Konklusion}

På bacheloruddannelsen i medicin/biomekanik ved Syddansk Universitet tilbyder vi de nyoptagne studerende, at de kan deltage mere eller mindre aktivt i studieforberedende aktiviteter på nettet allerede før den første semesterstart.

Førstudiestartskurset bygger på en formodning om, at de nyoptagne studerende naturligt er nysgerrige efter at lære mere om deres nye studie, og at den nysgerrighed og motivation til at sætte sig ind i rollen som universitetsstuderende ikke mindst er til stede i perioden fra den studerende modtager meddelelse om optagelse på studiet, til semestret går i gang 4-5 uger senere. Førstudiestartskurset giver de nye studerende mulighed for at udnytte deres nysgerrighed og motivation til at forberede sig på studiet gennem at læse information om studiet og universitetet, bruge relevante studieværktøjer i praksis, og indlede opbygningen af studierelevante, sociale netværk allerede i ugerne op til semesterstarten.

Det er vores vurdering, at tilbuddet indtil nu har været godt modtaget af de nye studerende.Vi kan ikke dokumentere, at førstudiestartskurset i sig selv har en positiv effekt på de studerendes studieprogression. Men vi mener at have mange gode argumenter for, at et netbaseret førstudiestartskursus er et relevant og passende tiltag, når man 1) ønsker at give de nye studerende mulighed for at forberede sig godt på de krav, der stilles til dem i deres nye rolle som universitetsstuderende på et bestemt studium, 2) ønsker at give dem mulighed for helt konkret at øve sig i brugen af relevante studieværktøjer som fx e-læringsværktøjet allerede før semesterstart, og 3) i det hele taget gerne vil vise de nye studerende, at de er velkomne og ventede.

Udviklingen og implementeringen af førstudiestartskurset kræver samarbejde og koordination mellem undervisere og studieadministrative organer og helst også inddragelse af studenterorganisationer o. lign. Når førstudiestartskurset er udviklet, kan det indgå som en naturlig del af en tidssvarende indgang til universitetsstudiet. Førstudiestartskurset er ikke blot en digital brochure, men er et forsøg på at sætte rammer for, at den nye studerende kan øve sig i at være studerende allerede før semesteret går i gang.

\section{Noter}

1 Invitationen til deltagelse blev sendt til 220 personer, som forventedes at begynde på uddannelsen i september 2007. Ud af disse var der 32, som aldrig dukkede op til studiet, og som derfor ikke er regnet med i denne opgørelse.

2 Analysen er foretaget af statistiker Dorthe Almind Jensen fra Institut for Sundhedstjeneste, Forskningsenheden for Epidemiologi, SDU. Grundlaget er brugerdata for hele første modul af uddannelsen. Data antyder ikke en forskel på brugen før hhv. efter semesterstarten. Den samlede analyse kan rekvireres ved henvendelse til forfatteren.

3 Ca. halvdelen af de studerende, der optages på medicin og biomekanik ved SDU optages gennem kvote 2. Studerende, der optages gennem kvote 2, har typisk lavet forskellige studierelevante aktiviteter efter afsluttet gymnasieuddannelse, eller de har anden uddannelsesmæssig baggrund. Studerende, som ønsker optagelse gennem kvote 2, skal indgive begrundet motivation, på baggrund af hvilken de udtages til individuelle interviews.

4 Aktiv deltagelse er defineret ved, at den studerende som minimum har taget en quiz og/eller har skrevet en præsentation i det virtuelle møderum

5 Halvdelen af de nyoptagne får tilbud om studiestartskursus, halvdelen gør ikke. Studiestartsgrupper sammensættes, så de er 'rene' grupper af studerende, der har eller ikke har fạet tilbud om førstudiestartskursus. Sammenligning af studieprogression mellem de to grupperinger vil indikere en evt. effekt af førstudiestartskurset 